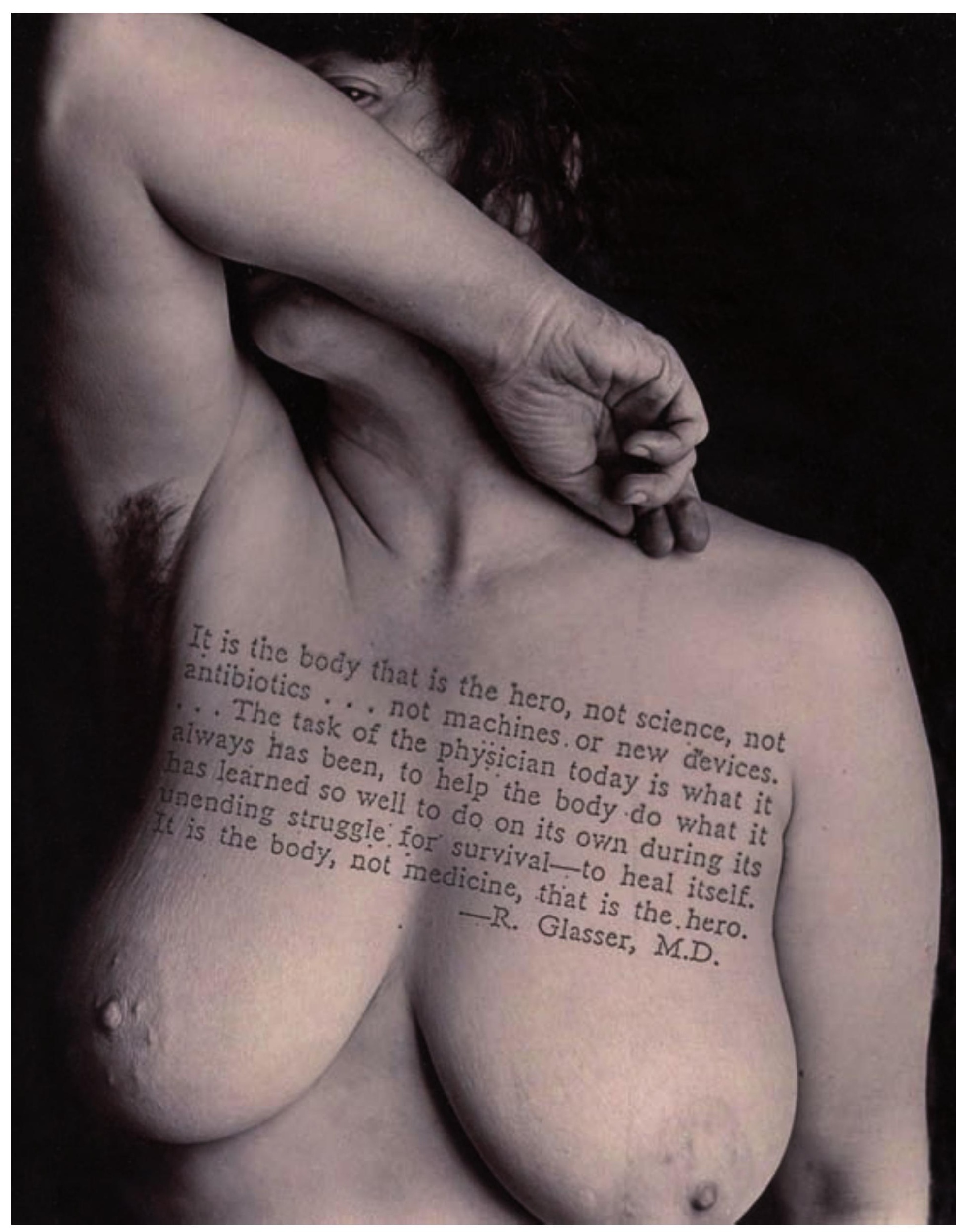




\section{MIRAR-SE DE CARA A L'ESPILL JO SPENCE I HANNAH WILKE}

Jesús MARTíneZ Oliva

El càncer ha estat durant molt de temps una malaltia tabú assetjada per l'ocultació i el silenciament social i per la consegüent exclusió del marc de la representació visual i artística. Aquest text pretén posar en relleu el paper pioner de dues artistes -Hannah Wilke i Jo Spence- que en la dècada dels vuitanta van trencar amb la por i el pudor a representar aquesta malaltia i van introduir en la seua obra les seues experiències, viscudes en primera persona, del càncer. L'autoretrat fotogràfic, seguint diverses estratègies que van de la fototeràpia a la labor desconstructiva d'estereotips i tabús o la militància crítica, serveix a aquestes autores per a enfrontar-se personalment a aquesta patologia i intentar desentranyar les metàfores i estigmes que l'envolten socialment i culturalment.

Paraules clau: Càncer, visibilització, autoretrat, fototeràpia, desconstrucció crítica, articulació del gènere femení, Hannah Wilke, Jo Spence, Marie Mandy.

Les connexions entre malaltia i representació artística són de molt divers signe i vénen de llarg. Per trobar la presència de la malaltia en l'art ens podríem remuntar a l'antiguitat i a la creació de tota una sèrie d'amulets i talismans amb finalitat sanadora. Però no sols s'ha donat aquesta relació benefactora, també la presència de cossos malalts en la història de la representació ha servit per a donar forma a l'abjecció i a allò que cal denigrar i estigmatitzar socialment. Una altra reblada, fins i tot més radical, d'aquest enfocament és la generació d'un tabú silenciador entorn de determinades afeccions que s'enquisten en l'ocultació i la consegüent exclusió del marc de la representació. D'altra banda, determinats enfocaments i teories estètiques han vist la malaltia com un esperó per a la creativitat. La presa de consciència del propi cos, el dolor o la reflexió sobre la mortalitat associades a les xacres i malalties generen un estat depressiu que propiciaria la coneguda malenconia creativa a què Albrecht Dürer va dedicar el seu cèlebre gravat Melancholia I i de la qual les teories romàntiques de l'art han tret tant de profit (només cal recordar que hom pensava que les fases finals de la tuberculosi propiciaven la creació o la importància que hom va atorgar a la bogeria).
No obstant això, i acostant-nos al nostre present -i ja lluny d'enfocaments romàntics-, dues malalties com el càncer i la sida han reactivat la creació contemporània entorn de la malaltia en l'últim quart del segle passat. Dues afeccions maleïdes i sense guariment definitiu, que, com Susan Sontag analitza en les seues conegudes anàlisis culturals sobre aquestes malalties, estan socialment farcides de tabús i metàfores estigmatitzadores. Un bon nombre d'artistes i literats que van viure en primera persona, o molt de prop, aquestes malalties es van llançar a analitzar minuciosament aquesta experiència per mitjà de l'autobiografia, del diari personal i de l'autoretrat fotogràfic. Aquest és el cas tant de l'obra de l'artista americana Hannah Wilke (194093) com la de la fotògrafa anglesa Jo Spence (1934-92), les produccions de les quals es van centrar en la representació fotogràfica de la malaltia del càncer una vegada que elles mateixes van ser diagnosticades d'aquesta afecció, encara que Wilke ja havia fet una incursió en el tema quan sa mare va haver de lluitar contra un càncer de mama. Totes dues són pioneres a donar visibilitat a una malaltia silenciada i emmascarada durant molt de temps i no sols en el camp de l'art sinó també -i de manera més sagnant-en 


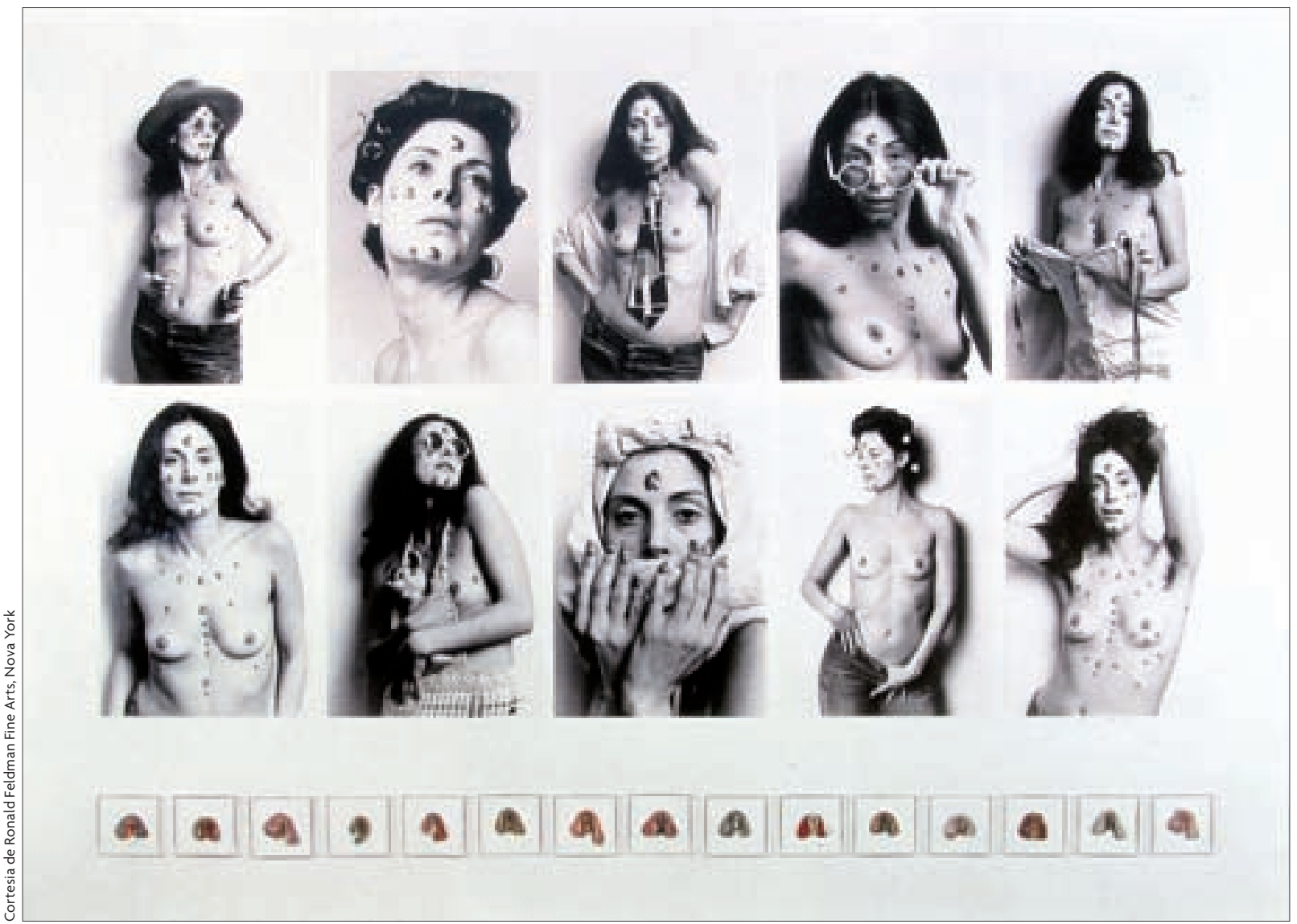

Hannah Wilke. S.O.S. Starification Object Series, 1974-82. Còpies en gelatina de plata amb escultures de xiclet, dimensions variables.

l'àmbit social. Mitjançant diverses estratègies, que van des de la fototeràpia fins a la militància crítica, aquestes artistes utilitzen l'autoretrat per confrontar tant el silenci i l'ocultació com la denigració i commiseració que la societat occidental exerceix sobre els cossos malalts $i$ en especial sobre el de les dones amb càncer.

En aquest sentit, el cas de l'obra de Wilke és paradigmàtic, ja que revela la importància dels paràmetres de gènere en la vivència física i psicològica d'aquesta malaltia. El seu treball des de mitjan anys seixanta es va centrar en la celebració de la fisicitat del cos de la dona (obres de làtex i argila amb formes vulvars que es van avançar a l'art vaginal dels anys setanta) i va utilitzar el propi cos per a un bon nombre de peces fotogràfiques i de performances. Peces com l'emblemàtica S.O.S. Starification Objects Series (1974) jugaven de manera ambivalent entre la glorificació de la dona en la cultura popular i la crítica al pes opressor que la societat patriarcal exerceix sobre les dones simplement per haver nascut amb una determinada marca de diferència sexual. L'artista apareix imitant un repertori de les postures sexies i coquetes de les models publicitàries i coberta amb una sèrie de cicatrius en forma vaginal fetes amb xiclet. Els marcadors sexuals situarien de manera predeterminada els individus en la societat amb un estatus o un altre de poder. Als ulls del feminisme més ortodox el seu atractiu físic va ser un impediment per a una lectura seriosa del seu treball de tipus crític, ben al contrari se li va acusar de narcisista i de reforçar les estratègies d'objectualització del cos femení imperants en la cultura occidental. Aquesta reacció contra el seu treball va canviar radicalment en els noranta, quan es va presentar de manera pòstuma la seua sèrie Intra-Venus Series a Nova York el 1994. Aquest conjunt de treballs fets després que se li diagnosticara un limfoma el 1987 consisteix en una sèrie de dibuixos i de fotografies en què la mateixa artista continua sent el focus d'atenció però ara amb el

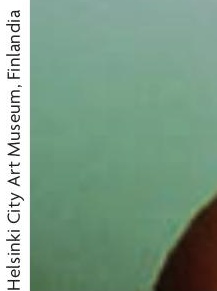



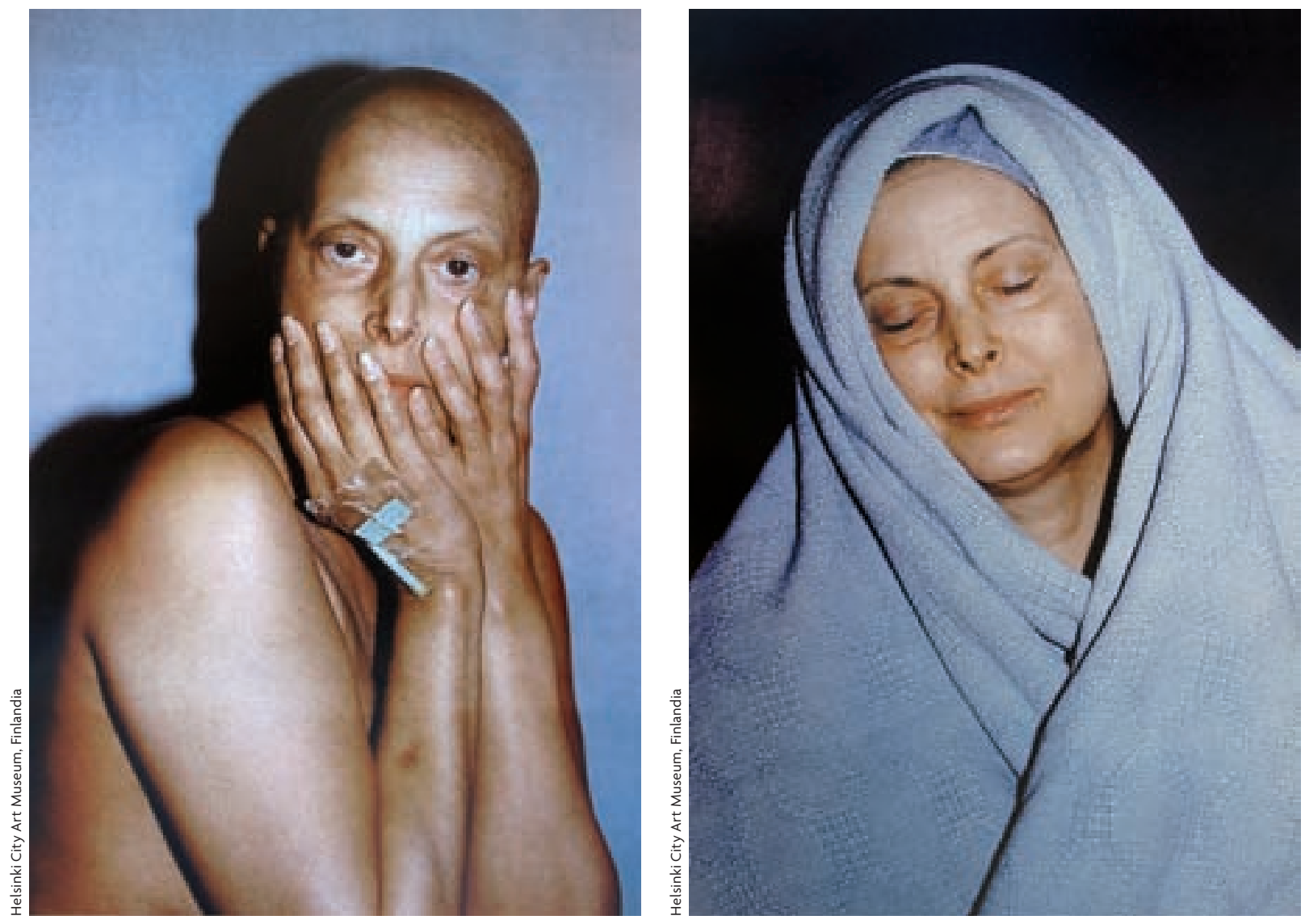

Hannah Wilke. Intra-Venus Series \#4, 26 de juliol i 19 de febrer de 1992, 1992. Fotografia cromogènica en paper Supergloss (díptic), 122,61x 183,61 cm.

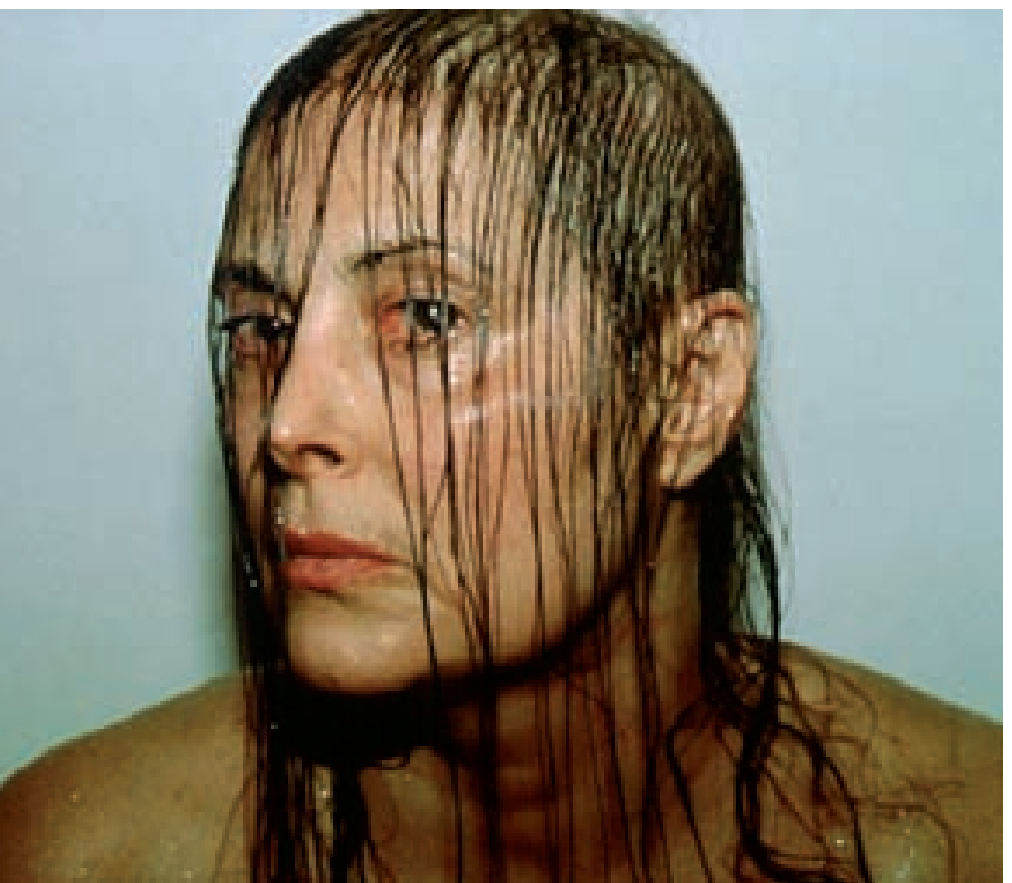

Hannah Wilke. Intra-Venus Series \#6, 19 de febrer de 1992, 1992. Fotografia en papel cibachrome. seu cos devastat per la malaltia. El títol (Intra-Venus) fa al·lusió per un costat a Venus, deessa de la bellesa i de l'amor en la mitologia i l'art occidental, i per un altre a la medicació i l'alimentació intravenosa a què es va sotmetre en l'hospital. En les fotos l'autora fa una citació paròdica de les convencions estètiques i arquetips femenins de dona bella, en els quals ella mateixa havia estat encasellada, però prescindint de tots els additaments de la mascarada femenina. Sense cap pudor i trencant tabús apareix sense maquillar, amb el cos inflat i sobretot (en gran part de les imatges) sense cabells, posant en escena actes, poses i gestos d'una feminitat exagerada. Així la veiem posant com una femme fatale, figura amb què tradicionalment l'havien vinculada en el món de l'art tant homes com dones, però calba i amb vies en les mans, que recolzava sobre el rostre; mirant a la càmera amb la boca oberta, que al·ludeix a Gestures, una peça de 1974 en la qual amb les mans es crea suggestius orificis en la cara, que converteix en un cos penetrable, però que ací simplement és oberta perquè siga penetrada per a una auscultació mèdica; coberta amb una manta blava d'hospital com una marededéu; nua amb un gerro al cap a la manera d'una Venus; o joguinejant sen- 


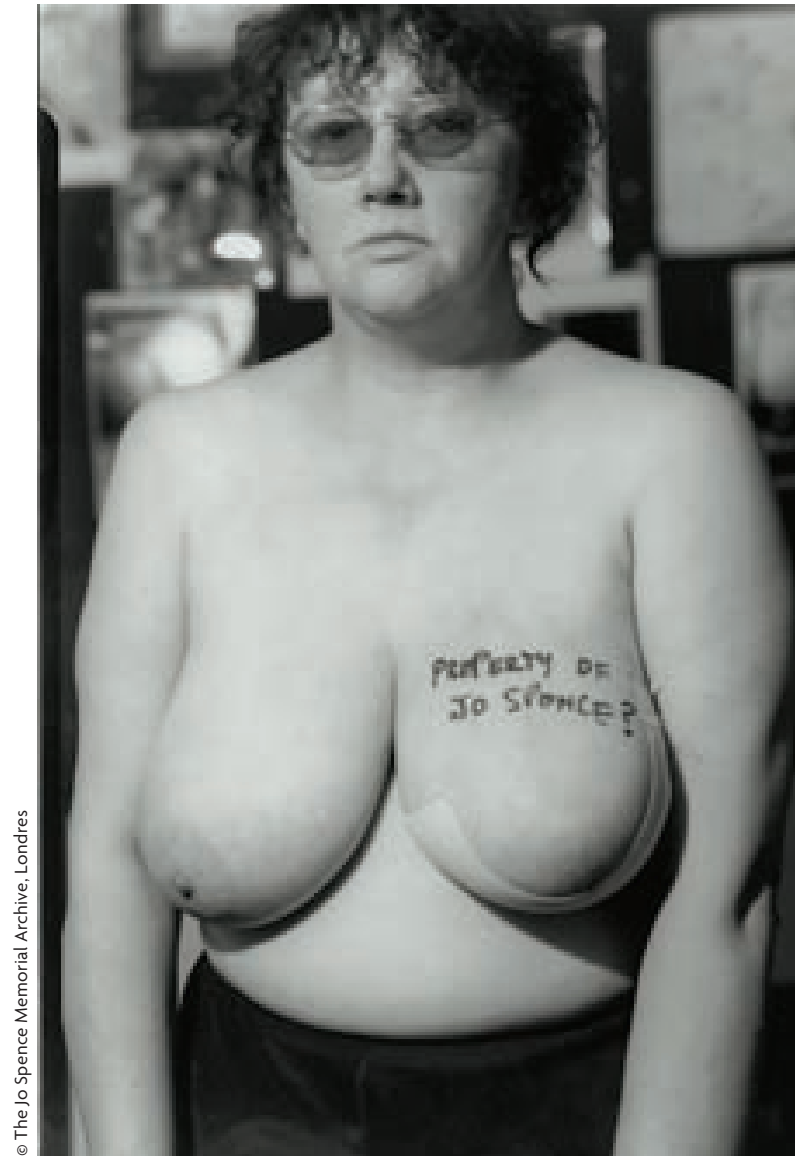

sualment en un llit de llençols blancs com en un quadre de François Boucher, però amb apòsits a les natges. La mirada objectualitzadora és doblement negada davant del seu cos malalt, contaminat, debilitat i botinflat pels tractaments. La malaltia la va obligar a distanciar-se de la seua pròpia bellesa i de les normes estètiques de la feminitat; aquesta distància li permet desconstruir la idea de la imposició d'una identitat de gènere normativa i al mateix temps d'un cos sa, jove i vigorós. Les dones amb càncer han d'enfrontar-se no sols al deteriorament físic sinó també a la pressió de la pèrdua de dos significants fonamentals de la feminitat normativa com són els pits i els cabells. L'ús de perruques i de pròtesis mamàries mostra de manera dramàtica el caràcter performatiu del gènere que va assenyalar Judith Butler i també el del cos sa. El gènere, la sexualitat i el cos sa són construccions culturals ideals a les quals hem de respondre constantment i que generen grans dosis d'ansietat, i en el cas de les pacients de càncer de manera redoblada. Wilke, amb tota sinceritat, exhibeix la degeneració del seu cos -abans bell- desfent al mateix temps tota una sèrie de clixés de gènere i de tabús representacionals a l'entorn del càncer, mostrant-se com una dona valenta que riu davant de la malaltia i la mort.

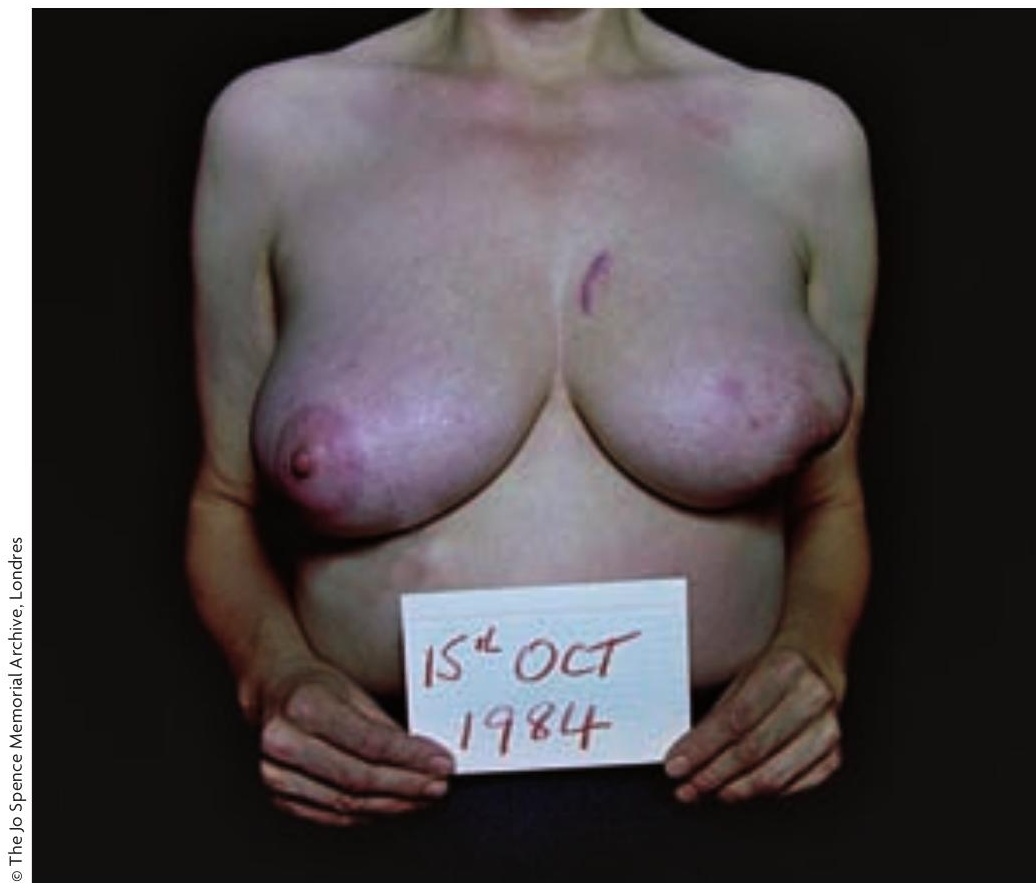

Esquerra, Jo Spence i Terry Dennett. The Property of Jo Spence, 1982-86. Pertanyent a The Picture of Health?

A dalt, Jo Spence i Terry Dennett. 15th October, 1984, 1984. Pertanyent a The Cancer Project.

A la dreta, Jo Spence i Terry Dennett. Crash Helmet Portrait, 1983. Pertanyent a The Picture of Health?

\section{"JO SPENCE VA AFRONTAR AMB GOSADIA \\ LA REPRESENTACIÓ DEL CÀNCER PER \\ MITJÀ DE LA FOTOGRAFIA COM UNA EINA \\ DE PODER TERAPĖUTIC I AMB GRANS POSSIBILITATS PEDAGÒGIQUES»}

El treball de Jo Spence també va afrontar amb gosadia la representació del càncer per mitjà de la fotografia, entesa en el seu cas com una eina de poder terapèutic i amb grans possibilitats educatives i pedagògiques. L'autora, vinculada des dels inicis de la seua carrera a un feminisme militant d'arrel marxista, va participar en diversos projectes collectius educatius basats en la fotografia i va generar algunes exposicions com Women, Work and Wages (1973-75) o Who's Still Holding the Baby? (1978) en les quals s'abordava la situació de les dones respecte al treball, els salaris o l'atenció als nens. En aquests projectes es combinava la tradicional fotografia documental amb entrevistes, informació extreta de periòdics i material educatiu per a informar i despertar la consciència crítica de l'espectador sobre el problema abordat. El 1982, quan va saber que tenia un càncer de 


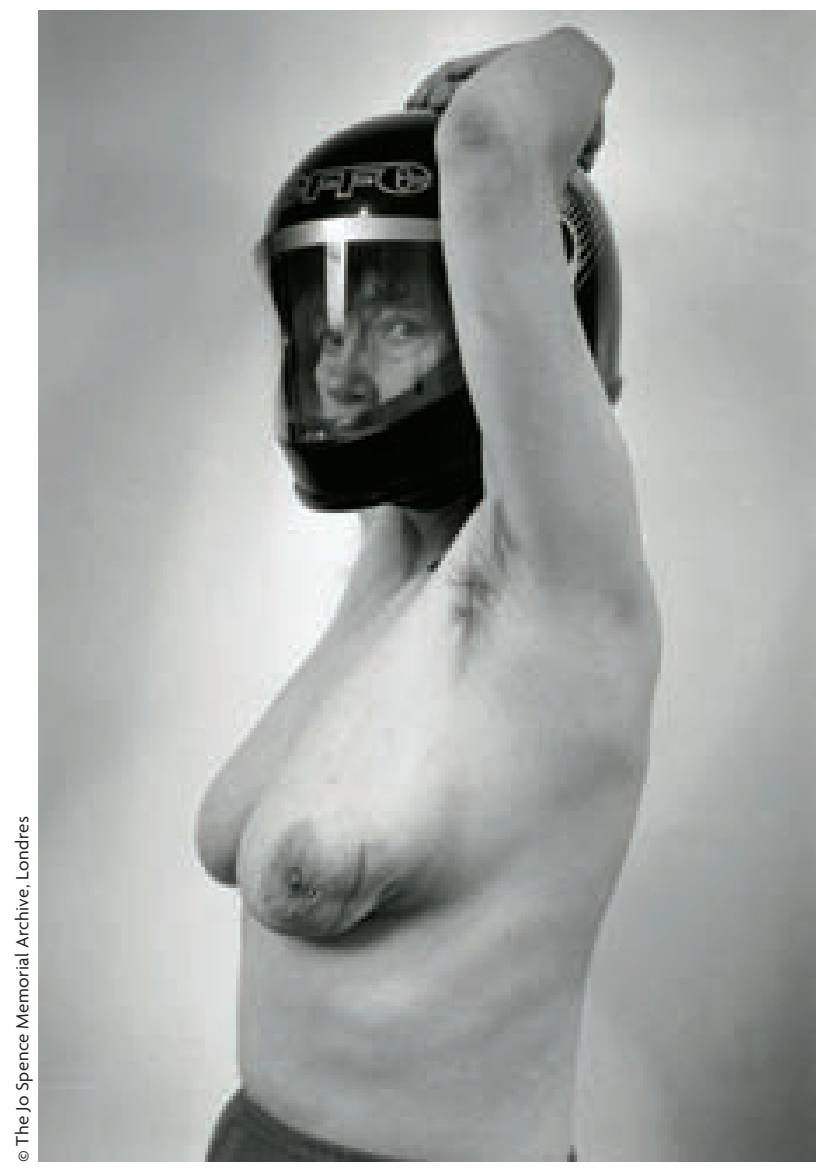

mama, el seu treball va fer un tomb i va passar del punt de vista social i dels problemes de classe a qüestions relacionades amb la seua subjectivitat i la seua salut, encara que mai va abandonar la visió i els modes de fer d'una pràctica artística compromesa políticament. Després de sotmetre's a una lumpectomia (cirurgia en què només s'extrau el tumor mamari i la part circumdant en compte d'extirpar tot el pit) i després de rebutjar la mastectomia que li recomanaven el metges, va realitzar The Picture of Health? (1982-91). En aquest projecte, igual com en la seua trajectòria anterior, pretenia educar l'espectador sobre un tema poc tractat, per no dir silenciat, i fer una crítica molt dura tant de la representació social de la malaltia com de les visions del cos sa i desitjable de la dona, com també de la institució mèdica. En primer lloc va realitzar una àmplia investigació sobre els diversos tractaments del càncer $i$ va descobrir la utilització per part de la institució mèdica dels malalts per experimentar amb diversos tractaments. Es va veure a si mateixa, amb gran sorpresa, inclosa en una llista secreta de persones que es podien sotmetre a assajos clínics. D’altra banda va trobar que hi havia tota una sèrie de tractaments alternatius menys agressius que donaria a conèixer mitjançant xarrades i articles per informar, educar i propiciar l'apoderament del pacient. Aquest projecte va sorgir de la seua pròpia experiència com a pacient $\mathrm{i}$ dels sentiments que va experimentar en ser tractada pel sistema mèdic i els seus protocols. Abans de ser operada es va sentir com un objecte que s'impersonalitza, es marca, se li priva de qualsevol veu i que s'infantilitza. En un dels panells fotogràfics apareix la pròpia artista amb la bata per a entrar a la sala d'operacions amb una gorra i un xumet o xuclant-se el dit, com si es tractara d'un bebè. Un altre dels panells està dedicat a l'actitud del pacient com a heroi o víctima i parodia, també amb humor, els reductors estereotips de l'imaginari social entorn dels malalts, amb el qual de manera maniquea s'és guanyador o perdedor, moralment fort o dèbil.

Per a la presentació de la seua tumorectomia es va fer un conjunt de fotos amb reminiscències de la fotografia policial que va dissenyar Alphonse Bertillon en el segle XIX. En 15th October, 1984, l'autora apareix de front i de perfil amb el cap tallat per assenyalar la pèrdua d'humanització en el seu tractament i l'anonimat dels pacients en el sistema mèdic. Mostra ostensiblement la cicatriu al pit i amb una cartel-la a la mà indica la data en què es va fer la foto i l'estat del seu cos en aquell moment. La fotografia de malalts i de criminals té concomitàncies per a l'autora. El cos del malalt és mesurat i arxivat com el d'un criminal. En alguns treballs últims, com The Final Project (1991-92), va treballar amb la superposició d'imatges. Per exemple en Decay Project I, 1984 (199192) reprèn fotografies antigues del seu cos dels anys vuitanta sobre les quals llisca una superfície clavillada, en descomposició, que ens parla de manera malenconiosa de la fuga del temps i de la preparació per a la mort. En aquesta mateixa línia es troba Looking Death in the Eye (1991-92), en la qual fa coincidir una calavera, imatge de la mort, amb els ulls de l'autora.

Els treballs d'aquestes dues pioneres en la representació del càncer ens poden incomodar, fer que desviem la mirada per evitar-los perquè ens acosten al patiment i al dolor, però en qualsevol cas són treballs exemplars que expliquen com afrontar i viure la malaltia de manera crítica, destapant tabús i defugint el victimisme. (

\section{BIBLIOGRAFIA}

DENNETT, T. et al., 2005. Jo Spence. Más allá de la imagen perfecta. Fotografía, subjetividad, antagonismo. Macba. Barcelona.

Hannah Wilke Collection \& ARCHive. <www.hannahwilke.com> Le BRETon, D., 1999. Antropología del dolor. Seix Barral. Barcelona. SANDER, G., 1988. Disease and representation; Images of Illness from Madness to AIDS. Cornell University Press. Ithaca.

SONTAG, S., 1996. La enfermedad y sus metáforas. El sida y sus metáforas. Taurus. Madrid.

SonTaG, S., 2007. Bajo el signo de Saturno. Debolsillo Ediciones. Madrid. SPENCE, J., 1995. Cultural Sniping: The Art of Transgression. Routledge. Londres. WILKE, H., 1995. Intra-Venus. Ronald Feldman Fine Arts. Nova York.

WILKE, H., (1940-1993), 2006. Hannah Wilke: exchange values. Artium. Vitòria.

Jesús Martínez Oliva. Professor del departament de Belles Arts, Àrea escultura, Universitat de Múrcia. 


\section{EL CÀNCER COM A METÀFORA: MARIE MANDY O EL DIARI D'UNA CURACIÓ}

\section{DOMINGO PUJANTE}

V incent van Gogh en les seues extraordinàries i commovedores Cartes a (el seu germà) Theo, on descriu la seua inestable salut física i mental, afirmava: «No em sembla impossible que el còlera, el mal de pedra, la tisi, el càncer, siguen mitjans de locomoció celeste, com els vaixells de vapor, els òmnibus i el ferrocarril ho són terrestres. Morir tranquil-lament de vellesa seria com anar a peu.» Les relacions entre malaltia i producció literària i artística al llarg de la història estan tan entrelligades com les que s'estableixen entre els mateixos individus i constitueixen un binomi especialment productiu. Són nombrosos els escriptors i artistes que han desenvolupat la seua obra emparats en la malaltia, pròpia o d'altri, i en el dolor profund que això produeix en la creació o l'escriptura. Sens dubte el gran antecessor modern de la utilització de la malaltia com a font d'alliberament és Charles Baudelaire i les seues poètiques Flors del mal, obra mestra de la literatura universal on la sexualitat ocupa una plaça d'honor en una època en què es banalitza la salut, com també ocorre en Madame Bovary de Gustave Flaubert. Precisament per aquesta raó ambdues obres es veuran condemnades per immoralitat. En efecte, en el segle XIX els sistemes morals i mèdics associaven algunes malalties epidèmiques a una immoralitat sexual, judici de valor que encara perdura avui dia i que castiga aquells desitjos que no se sotmeten als preceptes religiosos o morals. Així el poeta que va cantar aquelles Dones condemnades va morir de sífilis, aquell altre «mal finisecular», principal avantpassat, quant a producció literària i vehicle d'imatges, de la sida, mal que s'ha presentat als ulls de la imaginació collectiva contemporània com a epidèmia, nova «pesta» de la nostra època, i que es converteix al seu torn en la malaltia més transgressora de la nostra era, ja que afecta un dels grans tabús de la societat occidental i judeocristiana: la sexualitat $i$ els vincles o unions que se'n deriven. Aquestes malalties i les (auto) ficcions corresponents esdevenen un gran revulsiu social, bon punt sobrepassada la primera etapa d'aparició de la culpa, producte de la identificació, a manera de metàfora anticipant, entre estar dolent i ser dolent.

El càncer, fins i tot desproveït de la sobrecàrrega estigmatitzant que comporta la sexualitat, és una altra de les malalties «innominables», a desgrat de la contínua

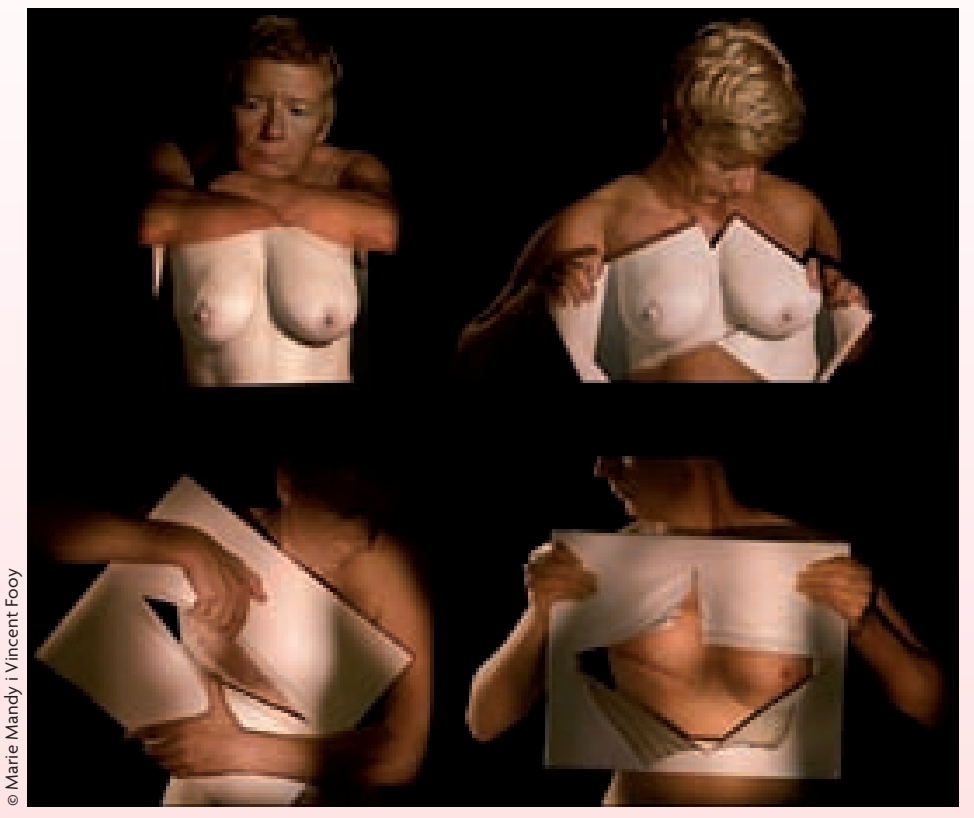

mediatització de què és objecte actualment, particularment present en la producció artística, fílmica i literària contemporània. De manera general les constants que apareixen en aquestes obres de caràcter altament autobiogràfic i testimonial són: l'aspecte mèdic o de relació directa del protagonista (dona en molts casos) amb la malaltia i tot el que d'aquest contacte es deriva; la importància de la creació com a acte terapèutic i com a metàfora de les empremtes que la malaltia deixa al cos de qui la narra (metàfores a què al-ludeix la novellista i assagista Susan Sontag, i a qui va fotografiar en la intimitat i quotidianitat de la seua malaltia la seua companya Annie Leibovitz); les reflexions intimistes i quasi ontològiques sobre el sentit i la transcendència de la vida on el tractament del temps adquireix una especial rellevància (importància de la forma del diari íntim) i finalment les relacions humanes (entorn familiar, mèdic, laboral...) en la seua accepció més àmplia. Un dels exemples més representatius en aquest sentit és el treball de la realitzadora belga Marie Mandy (Lovaina, 1961) titulat Mes deux seins. Journal d'une guérison (2010) ("Els meus dos pits. Diari d'una curació") de 92 minuts. Mandy tria una vegada més la forma documental, de fort compromís i realisme social però alhora altament poètica i estètica, en la qual s'ha especialitzat (recordem a títol d'exemple el seu anterior Filmer le 
désir (2001) ("Filmar el desig") en el qual explora el desig femení a través del cine de dones o el premiat Voir sans les yeux (2004) ("Veure sense ulls") on ens ofereix cinc impactants retrats de persones invidents (o quasi) com si hagueren estat filmades a través dels seus propis ulls). Els meus dos pits és una narració audiovisual en forma de diari íntim sobre la seua pròpia experiència del càncer. Des de les pors a anar al metge després de descobrir-se un bony al pit dret, fins al dolorós procés que passa per l'acte quirúrgic de la incisió corporal, el to que adopta la cineasta, simple, pròxim i sincer, on no tenen cabuda sentimentalismes impostats ni tabús, no deixa indiferent l'espectador. Junt amb la pel-lícula, demana a Vincent Fooy que la fotografie en els moments clau d'aquest procés cap a la curació, des del diagnòstic a l'ablació del pit. Aquestes cinquanta fotografies memorials que impacten sobretot per la gran bellesa visual i compositiva constituiran un catàleg i una exposició titulada Par les yeux d'une Amazone ("Pels ulls d'una amazona"), ja que va decidir no fer-se la reconstrucció mamària. Partint de la metàfora de la pell com a llenç, o la idea de les escarificacions o els tatuatges primitius, es projecten unes imatges de vídeo sobre les sines abans de fer aquesta sèrie de fotografies que compten les etapes d'aquest particular via crucis cap al guariment, en un intent de representar sobre el cos el que se sent internament per tal d'exor-

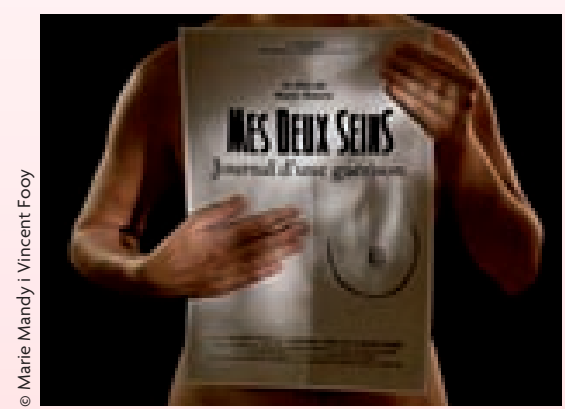

«EL TREBALL DE MARIE MANDY IL.LUSTRA PERFECTAMENT L'ABAST TERAPĖUTIC D'AQUESTA CONFESSIÓ ÍNTIMA I

EXEMPLAR QUE COMPORTA LA GOSADIA DE VĖNCER EL TEMOR I TRENCAR EL SILENCI" través d'altri, com la tuberculosi en la Dama de les camèlies d'Alexandre Dumas fill, el seu Diari filmat naix directament de la malaltia sense artificis. Com ocorre amb els escriptors de la sida, que sovint adopten igualment la forma urgent del diari íntim, és la malaltia qui l'escriu i qui és alhora subjecte, objecte i tema del relat. Així la realitzadora s'autoretrata, esdevé observadora i cronista, exposa les seues reflexions, els seus dubtes, les seues pors, les seues opinions respecte a la relació amb si mateixa i amb els altres (molt especialment l'entorn mèdic). Es tractaria en última instància d'un exercici de «confessió», però entesa no en el sentit cristià de secret o de culpa sinó més aviat en el sentit clàssic d'autoafirmació. Som, doncs, davant d'un acte alliberador, allò que Michel Foucault denomina una «estètica de l'existència», que es recolza essencialment en el potencial de resistència del subjecte més que no en el dret de crítica sobre si mateix. L'autora diu la seua veritat i s'hi enfronta de manera valenta, sense cap tipus de justificació. D'aquesta manera, donant la cara, s'opera una afirmació de si mateixa, una resistència, una reivindicació que no és motiu d'afront, ben al contrari, és arma per lluitar contra qualsevol forma d'hipocresia, contra una imatge deformada de la seua persona imposada per un altre. En posar-li paraules i imatges a la seua vivència del càncer, se n'allibera en un cert sentit, o de part del patiment, com indica la «curació» del títol. Mandy es posa en discurs de manera responsable tora reconeix la dimensió plàstica del seu treball, la influència que han tingut altres obres d'altres artistes que han tractat el tema i el seu desig de ser una anella més d'aquesta cadena d'artistes. El treball fílmic de Mandy, que parteix dels rituals mèdics i dels ritmes quotidians marcats per la malaltia, illustra perfectament el gran valor artístic i antropològic d'aquestes noves formes d'autoficció contemporànies, així com l'abast terapèutic d'aquesta confessió íntima i exemplar que comporta la gosadia de vèncer el temor i trencar el silenci. A diferència de l'escriptura vuitcentista, Marie Mandy deixa completament de costat l'aspecte moralista i realitza aquesta narració fílmica sobretot per i per a si mateixa. Lluny de traslladar als seus personatges les pròpies malalties i donar-los nom a sense culpabilitat ni innocència, sense juís morals, la qual cosa comporta una relació de sinceritat amb si mateixa que arriba profundament a l'espectador, ja que aconsegueix ser el que ella vol ser, aquella «amazona dels temps moderns» en les seues pròpies paraules, i no el que els altres volen que siga. Així doncs, sense caure en la facilitat de les glosses sobre la «malaltia benèfica», el càncer, que és també un relat, provoca l'obra (fílmica en aquest cas) i, per mitjà d'aquesta extraordinària pel-lícula i aquestes fotografies, provoca la reflexió i la normalització de la malaltia contra totes les temptatives d'estigmatització i d'ocultació. ()

Domingo Pujante González. Professor titular. Departament de Filologia Francesa i Italiana, Universitat de València. 